\section{Innovative Solutions for Local Public Administration in the Process of the Waste Collection}

\section{Răzvan Aurelian MUNTEANU1}

${ }^{1}$ Bucharest University of Economic Studies, Bucharest, Romania, razvanmunteanu2009@gmail.com

\begin{abstract}
Sustainable development has always been one of the most important policies implemented by the European Union, mentioned in different treaties over time. In 2015, European Union is setting 17 Sustainable Development Goals (SDG) with 169 targets within the 2030 Agenda for Sustainable Developement. European Union is preseting the SDG 11 Goal aim "to renew and plan cities and other human settlements in a way that they offer opportunities for all, with access to servicies, energy, housing, transportation, green public spaces, while improving resource use and reducing environmental impacts".

The EU is monitoring the progress towards SDGs for all member states through different indicators, like the recycling rate of municipal waste for SDG 11. In 2018, Romania has the recyling rate of municipal waste of only $11,11 \%$, far away from the average of EU of $47,4 \%$.

The local public administrations have an important role in increasing the recyling rate, by providing the best services for the citizens and, in the same time, by reducing the costs of these services. In this matter, the paper presents an innovative solution regarding the waste collection in the largest District from Bucharest, Romania.

The underground waste collection platforms represent and alternative for the classic platforms and the innovation comes from the smart component that they integrate, represented by the filling sensors that communicate directly to the sanitation operator.

The monitoring system has direct effect by incresing the efficiency of the waste collections process, as follows: reduces the waste collection cost by $50 \%$; improves the services provided for the citizens; predicts waste generation patterns based on data; refines waste collection processes over time; optimizes routing and navigation etc.
\end{abstract}

Keywords: innovation, sustainable development, waste collection.

How to cite: Munteanu, R. A. (2020). Innovative Solutions for Local Public Administration in the Process of the Waste Collection. In I. M. W. Staniewski, V. Vasile, \& A. Grigorescu (vol. ed.), Lumen Proceedings: Vol. 14. International Conference Innovative Business Management \& Global Entrepreneurship (IBMAGE 2020) (pp. 140-156). Iasi, Romania: LUMEN Publishing House. https://doi.org/10.18662/lumproc/ibmage2020/11 


\section{Introduction}

One of the first moments in the history of sustainable development concept is The Conference of the Human Environment, from Stockholm, in 1972, where 113 states attended to discuss about the link between environment and development [1]. Taking into account the importance of the new concept, in 1983, the United Nations created the The World Commission on Environment and Development (Brundtland Commission), which in 1987, published the Brundtland Report entitled Our Common Future that given the definition of the sustainable development as follows: "sustainable development is development that meets the needs of the present without compromising the ability of future generations to meet their own needs" [12]. This definition is underlying the limitations given by resources in order to meet the needs of the population.

In September 2015, United Nations adopted The 2030 Agenda that establishes 17 objectives for sustainable development (SDG). European Union committed to make all the efforts in order to implement all the objectives while sustainable development has always represented one of the central concern in all the treaties [10].

The 2030 Agenda for Sustainable Development has 17 objectives with 169 targets. SDG 11 Goal aim "to renew and plan cities and other human settlements in a way that they offer opportunities for all, with access to services, energy, housing, transportation, green public spaces, while improving resource use and reducing environmental impacts" [14].

\section{Problem Statement}

Waste collection is an important part of the environmental policies and represents one of the challenges for public authorities worldwide because as urbanization is increasing, especially in developing countries and growth of population. Ineffective waste management and weak policies may lead to the degradation of valuable land resources, a rise in the land price and the creation of long-term environmental and human health problems [2].

Establishing a sustainable waste management system remains a tough task for many governments, especially in developing countries that are experiencing rapid urbanization, with limited financial resources available for investment [5; 6; 7]. Along with the improved economic conditions, unprecedented urbanization process and changing life patterns, local authorities in many developing countries are facing a major challenge by coping with rapidly increasing amounts of municipal waste $[3 ; 4 ; 8]$. 


\section{Research Questions/Aims of the research}

The main purpose of the research is to analyse an innovative solution in the process of waste collection in a local public administration from Romania. The research presents an investment from one of the biggest districts of Bucharest, as best practice that can be implemented in other local public administrations.

\section{Research Methods}

In the first part of the study, we used as main research method the quantitative analysis of indicators regarding the recycling rate of municipal waste and qualitative analysis regarding the legal framework for the waste management in European Union and Romania. The indicators are taken from Eurostat database and the qualitative analysis is based on the European Union`s directives regarding waste management and Romania's National Sustainable Development Strategy 2030.

In the second part of the study it is analysed the estimate budget of an innovative solution for waste collection in the first district of Bucharest, based on two options.

\section{Findings}

\subsection{Waste collection in European Union}

As presented by Eurostat, the recycling rate of municipal waste represents the tonnage recycled from municipal waste divided by the total municipal waste arising. Recycling includes material recycling, composting and anaerobic digestion. Municipal waste consists mostly of waste generated by households, but may also include similar wastes generated by small businesses and public institutions and collected by the municipality.

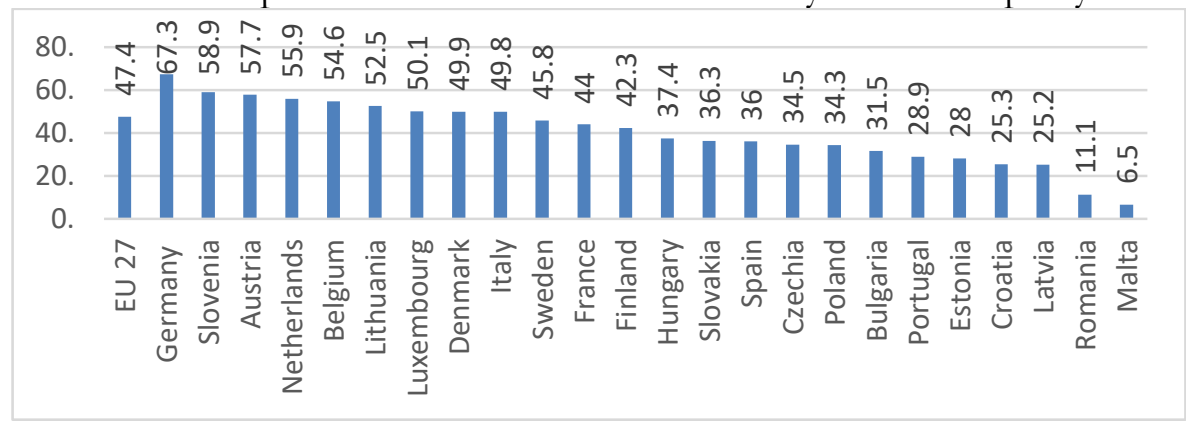

Graphic no. 1 The recycling rate of municipal waste, in 2018, in European Union (\%). Source: processed data from Eurostat [9] 
In table no. 1 is presented the recycling rate of muncipal waste from all the European Union states. It can be noticed that the average rate in EU is $47,4 \%$ of municipal waste that it is recycled and the highest rate is reported in Germany with 67,3\% [9]. Germany is leader in European Union due to the policies adopted by the Gouvermanet, like: Packging Ordinace, Closed Substance Cycle and Waste Management Act, Green Dot etc. Another important aspect that leads Germany is the culture of people for recycling that helps authorities to reduce costs of pre-sorting.

Regarding the recycling rate from Romania, of only $11,1 \%$ in 2018 , it is noticed that is far under the European Union average. As Bucharest is the biggest municipality from our country, with the highest number of inhabitants, represeting $9 \%$ of the national population, the amount generated by waste represents $20 \%$ of the amount generated at national level. The resulting household waste generation indicator is about 0.9 $\mathrm{kg} /$ inhabitant/day, being higher than the national average indicator for the urban environment, which is $0.67 \mathrm{~kg} /$ inhabitant/day. If the EU 28 average is $476 \mathrm{~kg} /$ inhabitant per year in Bucharest, the municipal waste generation indicator is $562 \mathrm{~kg} /$ inhabitant/year.

\subsection{Analysis of the legal framework on waste collection}

The European Commission adopted and published in the Official Journal of the European Union on 14.06.2018, a package of measures aimed at stimulating Europe's transition to a circular economy. This package of measures includes proposals for the revision of waste legislation, as well as a related action plan. Waste proposals set out a long-term vision for increasing recycling and reducing landfill. The directives that have been revised following the adoption of the circular economy package are: Directive 2008/98/EC on waste and repealing certain Directives; Directive 1999/31/EEC on the disposal of waste; Directive 2006/66/EC on batteries and accumulators and waste batteries and accumulators and repealing Directive 91/157/EEC; Directive 2011/65/EC on restrictions on the use of certain hazardous substances in electrical and electronic equipment; Directive 2012/19/EU on waste electrical and electronic equipment; Directive 2000/53/EC on end-of-life vehicles; Directive 94/62/EC on packaging and packaging waste.

The Waste Management Framework Directive requires EU countries to meet very ambitious municipal waste recycling targets, namely $55 \%$ by $2025,60 \%$ by 2030 and $65 \%$ by 2035 . Romania has a recycling rate of around $11,1 \%$, risking entering into infringement for not reaching the set targets. Municipal waste management is the attribute of local government, which contributes to achieving national targets. 
Romania's National Sustainable Development Strategy 2030 provides as a target for 2020 - Increasing the company's readiness for reuse and recycling by applying the waste management hierarchy, and in terms of medium and long term targets the strategy provides the following targets [13]:

a) Establishment of mandatory extended producer responsibility schemes for all packaging by 2024 .

b) $55 \%$ recycling of municipal waste by 2025 and $60 \%$ by 2030 .

According to European and national legislation, local public authorities must achieve the following targets:

- To reach, in 2020, a level of preparation for reuse and recycling of at least $50 \%$ of the total mass of waste quantities, such as paper, metal, plastic and glass from household waste. In order to stimulate the separate collection of waste from the population, it will be analyzed from a technical, economic and environmental protection point of view the opportunity to apply the economic instrument "pay for how much you throw away" used in most EU member states;

- To reach, in 2020, a level of preparation for reuse, recycling and other material recovery operations, including landfill filling operations that use waste to replace other materials, of at least $70 \%$ of the mass of non-hazardous waste quantities from activities construction and demolition;

- To reduce annually by $15 \%$ the quantities of municipal waste eliminated by storage;

- To collect biowaste separately, in order to compost and ferment it;

- To treat biowaste in a way that ensures a high level of environmental protection.

The revision of the Law 211/2011 provides in art. 14 obligations for both waste producers and economic operators who ensure the collection and transport of waste for separate collection. Unfortunately, the law is not applied, the producers collecting and handing over the waste in the mixture, and the sanitation operators lifting it in this form, or sometimes even being sorted, to be mixed even by the collector, when lifting.

\subsection{Short-term measures (horizon 2024), indicators and expected results}

Implementation of the provisions of Law 211/2011, art.17 and establishment of the new deadlines for implementation, for the following measures: 
- the achievement of a preparation target for reuse and recycling of at least 50\% (until 31 December 2020), at least for paper, metal, plastic and glass waste from household waste or, where appropriate, from other sources, to the extent that these waste streams are similar to household waste;

- the inclusion in the specifications and in the contracts for the delegation of the management of the sanitation service, of separate tariffs for the separate collection of waste;

- the inclusion in the specifications and in the contracts of delegation of the management of the sanitation service and in the regulations of the sanitation service of the performance indicators for each activity within the sanitation service, so as to reach from 2020 the recycling targets and penalties for their non-achievement;

- the implementation of the 'pay for how much you throw away' economic instrument (starting on 1 January 2019, but not later than 30 June 2019), based on at least one of the following: (i) volume, (ii) frequency (iii) weight, (iv) custom collection bags;

- the establishment and approval, (from 1 January 2019, but not later than 30 June 2019), for the beneficiaries of the sanitation service of separate tariffs for the separate collection of waste and the sanctions applied if the beneficiary of the service does not properly separate waste;

- the inclusion, starting with 1 January 2019, in the tariffs paid by the beneficiaries of the service of the contribution to the circular economy only for waste destined for disposal by disposal, taking into account the performance indicators;

- the support by the sanitation operators of the contribution to the circular economy for the quantities of municipal waste destined for disposal that exceed the quantities corresponding to the performance indicators provided in the contracts.

The achievement indicators for the First District of Bucharest are represented by a new contract or an addendum to the sanitation contract containing the provisions of law 211/2011 and a Decision of the Local Council of the First District of Bucharest on the tariffs applied to the beneficiaries of sanitation, including the economic instrument «pay for how much you throw». 


\subsection{Targets (horizon 2030) indicators and expected results}

The implementation of this measure should take place as soon as possible. The proposed deadline is the end of 2021. Romania's National Sustainable Development Strategy 2030 provides as targets for 2020 [13]:

- Continuing efforts at national level to improve resource productivity by including precise, rigorously monitored targets in all sectorial and development strategies in territorial profile in order to align with European standards and prepare for the transition to the circular economy model.

- Popularization and promotion of sustainable production and consumption models through information campaigns for the general public and efforts to expand these good practices in school and extracurricular educational programs.

- Increase the company's readiness for reuse and recycling by applying the waste management hierarchy.

And by 2030 , the strategy proposes the following targets:

- $55 \%$ recycling of municipal waste by 2025 and $60 \%$ by 2030 .

- $65 \%$ recycling of packaging waste by 2025 (plastics 50\%; wood 25\%; ferrous metals $70 \%$, aluminium $50 \%$, glass $70 \%$, paper and cardboard $75 \%$ ) and $70 \%$ by 2030 (plastics $55 \%$; wood 30\%; ferrous metals $80 \%$, aluminium $60 \%$, glass $75 \%$, paper and cardboard $85 \%$ ).

- Separate collection of hazardous household waste by 2022 , bio-waste by 2023 and textiles by 2025 .

These targets cannot be achieved without the contribution of the population, which must be well informed and educated so that the separate collection process can be carried out as easily and quickly as possible.

\subsection{Innovation solution in the process of waste collection in the First District of Bucharest}

The waste collection infrastructure faces a number of shortcomings due to the fact that the existing household points do not fully comply with the legislation in force and generate both inconvenience for citizens and risks to their health. Also, the existing infrastructure does not produce effects to reduce waste generation nor can it be properly tracked and monitored in order to be able to extract a statistic designed to reduce these quantities. Another weak point is that the collection of household waste is not optimized by composting at source, which could significantly reduce the amount of municipal waste. 
In order to comply with the European legislation in force, it can be stated that the waste collection infrastructure is outdated both physically and morally, being represented by household waste collection points, fence type, surrounded by wire mesh or concrete snail type, rubbish on the ground floor or basement with pipes, individual bins/containers, special trucks (garbage trucks, others) for collecting common waste, wet and dry fraction. In this regard, the efforts of local public authorities must be directed towards the issue of waste collection, so as to meet national and European objectives.

The proposed solution for increasing waste collection is represented by the implementation of an innovative waste collection system within the local community in the First District of Bucharest. The investment for the implementation of this modern and innovative system has as main source of financing the local budget and has as general objective to assurance of the observance of the legislative impositions regarding the public services.

The investment has a duration of about 10 months, for 500 underground collection points and targets a number of 1973 of sites, located within the administrative area, and the surface of the land occupied by each underground collection point is max $12 \mathrm{sqm}$, with a total area of 23,676 sqm.

The investment involves the implementation of underground waste collection points, which are an alternative to the classic platforms, represented by pens within which containers/bins are placed. The underground collection points have the following components [11]:

Above ground components:

- insertion baskets with controlled access system in order to use them. The baskets will be made of stainless steel (raw or painted) with folding system and pedal;

- the upper plate of the metal structure supporting containers pedestrian access - finished with concrete / paving / stone slabs depending on the location area (as for example in the historically protected area will be finished depending on the specifics imposed on the area), and the surroundings are they will arrange with access sidewalk (where applicable).

Underground component:

- waterproof prefabricated concrete tank;

- metal structure supporting/storing containers of $1.1 \mathrm{sqm}$;

- hydraulic system for lifting the metal structure in order to empty the containers of $1.1 \mathrm{sqm}$. (restricted access only to the operator / beneficiary of the collection point); 
- controlled access system (card or similar) users underground collection point and electronic system of information/warning filling containers/container collection point.

- the underground collection points are intended for the selective collection of household waste, on 1,2,3 or 4 fractions, depending on the organization of the service at the local level. Thus, an underground collection point is provided with 4 insertion baskets that can be destined, depending on the local Sanitation Regulation, to the established waste fractions.

- the system for identifying and weighing trash/containers is an IT solution for better municipal waste management. It combines specially designed hardware components for installation on collection trucks and a software application. The system allows the application of the payment model according to the waste generated ("Pay as you throw") for the disposal of municipal waste based on volume or mass criteria.

- the identification and weighing process must be completely automatic and not require any commitment from the workers.

- waste bins and containers are provided with special transponders with radio frequency identification (tags - chips). Each tag has a unique identification number, assigned to the owner of the bin/container. The identification process is completely automatic. Radio-frequency antennas mounted on a hydraulic lift automatically identify a tag when the bin is placed on the lift. Identification data is timed, recorded in real time and instantly displayed in the software application. The information flow ends with the automatic transfer of all relevant data to the software.

Table no. 1 General estimate of the project

Variant I - Containers $1.1 \mathrm{sqm}$. made of metal

\begin{tabular}{|l|l|l|l|l|}
\hline \multirow{2}{*}{ No. } & $\begin{array}{l}\text { NAME OF } \\
\text { EXPENDITURE } \\
\text { CHAPTERS }\end{array}$ & $\begin{array}{l}\text { VALUE } \\
\text { without VAT }\end{array}$ & VAT & $\begin{array}{l}\text { VALUE } \\
\text { including } \\
\text { VAT }\end{array}$ \\
\cline { 2 - 5 } & Lei & Lei & Lei \\
\hline $\mathbf{1}$ & $\mathbf{2}$ & $\mathbf{3}$ & $\mathbf{5}$ \\
\hline \multicolumn{4}{|l|}{ CHAPTER 1. EXPENSES PT. OBTAINING AND LAND PLANNING } \\
\hline \multicolumn{2}{|l|}{ TOTAL CHAPTER 1 } & 0,00 & 0,00 & 0,00 \\
\hline $\begin{array}{l}\text { CHAPTER 2. EXPENDITURE PT. ACHIEVING THE UTILITIES NECESSARY FOR } \\
\text { THE INVESTMENT OBJECTIVE }\end{array}$ & 0,00 & 0,00 \\
\hline \multicolumn{2}{|l|}{ TOTAL CHAPTER 2 } & 0,00 & 0,00 & \\
\hline
\end{tabular}




\begin{tabular}{|c|c|c|c|}
\hline TOTAL CHAPTER 3 & 11.341.060,00 & $2.154 .801,40$ & $13.495 .861,40$ \\
\hline \multicolumn{4}{|c|}{ CHAPTER 4. EXPENDITURE FOR BASIC INVESTMENT } \\
\hline TOTAL CHAPTER 4 & $\begin{array}{l}132.852 .212,0 \\
0\end{array}$ & $\begin{array}{l}25.241 .920,2 \\
8\end{array}$ & $\begin{array}{l}158.094 .132,2 \\
8\end{array}$ \\
\hline \multicolumn{4}{|c|}{ CHAPTER 5. OTHER EXPENSES } \\
\hline TOTAL CHAPTER 5 & $18.566 .529,60$ & $3.527 .640,62$ & 22.094.170,22 \\
\hline \multicolumn{4}{|c|}{ CHAPTER 6. EXPENDITURE FOR TECHNOLOGICAL TESTS AND TESTS } \\
\hline TOTAL CHAPTER 6 & 0,00 & 0,00 & 0,00 \\
\hline TOTAL & $\begin{array}{l}162.759 .801,6 \\
0\end{array}$ & $\begin{array}{l}30.924 .362,3 \\
0\end{array}$ & $\begin{array}{l}193.684 .163,9 \\
0\end{array}$ \\
\hline
\end{tabular}

Source: data processing Feasibility Study Services for elaboration of technicaleconomic documentation for the realization of selective waste collection system, Volume 1 - Written Parts, According to GD 907/2016 [11]

The general estimate of the project is presented in two variants, depending on the material used to obtain the containers. Variant I involves the purchase of a number of 7892 metal containers, with a capacity of 1.1 sqm., with 4 collection points for each underground collection point. Variant II involves the purchase of a number of 7892 plastic containers, with a capacity of 1.1 sqm., with 4 collection points for each underground collection point. Below is the estimate for each of the two variants. In order to make the proposed investment, a number of site-related issues need to be considered, namely:

1. The proposed location will have pedestrian access and within a radius of approx. $15 \mathrm{~m}$ possibility of road access for the garbage truck implicitly access for the necessary equipment for construction (backhoe loader, crane, etc.);

2. A visual inspection will be made, so that the underground collection point will not be positioned over some manholes at the utilities related to the buildings;

3. Where possible, the location will be made on green spaces in order to avoid underground utility networks, most of them being generally located in the sidewalk areas;

4. The embankments can be proposed on the sidewalks, so that the legal regime of the land allows the construction;

5. The location will not affect parking spaces, as much as possible;

6. In historically protected areas, the location of the platforms will be made in visually isolated areas (such as behind buildings, on the side of buildings, on secondary streets, etc.).

The general estimate in the case of Variant I amounts to 193.6 million lei, a value that includes VAT. 
- VALUE without VAT $\quad$ VAT $\quad$ Value with VAT

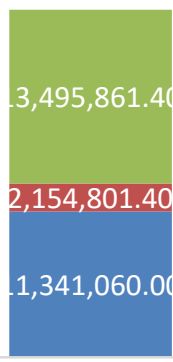

EXPENSES PT DESIGN AND TECHNICAL ASSISTANCE

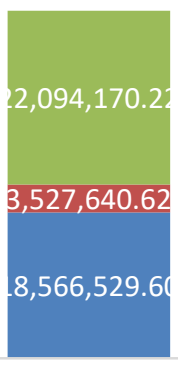

EXPENDITURE FOR OTHER EXPENSES BASIC INVESTMENT

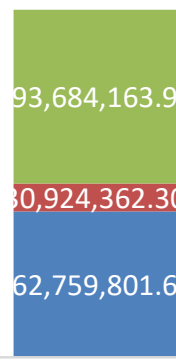

TOTAL

Graph no. 2 General estimate of the project

Variant I - Containers 1.1 sqm. made of metal

Source: data processing Feasibility Study Services for elaboration of technicaleconomic documentation for the realization of selective waste collection system, Volume 1 - Written Parts, According to GD 907/2016 [11]

Table no.2 Basic investment expenses, Variant I

\begin{tabular}{|c|c|c|c|c|}
\hline \multirow{3}{*}{\multicolumn{2}{|c|}{ Name of expenditure }} & \multicolumn{3}{|l|}{ VALUE } \\
\hline & & \multicolumn{3}{|l|}{ Lei } \\
\hline & & \multirow{2}{*}{$\begin{array}{l}\text { Without VAT } \\
100.133 .800,00\end{array}$} & \multirow{2}{*}{$\begin{array}{l}\text { VAT } \\
19.025 .422,00\end{array}$} & \multirow{2}{*}{$\begin{array}{l}\text { TOTAL } \\
119.159 .222,00\end{array}$} \\
\hline $\begin{array}{l}\mathrm{Ob} \\
1\end{array}$ & $\begin{array}{l}\text { Underground waste collection } \\
\text { points }\end{array}$ & & & \\
\hline $\begin{array}{l}\mathrm{Ob} \\
2\end{array}$ & Integrated electronic system & $29.818 .412,00$ & $5.665 .498,28$ & $35.483 .910,28$ \\
\hline $\begin{array}{l}\mathrm{Ob} \\
3\end{array}$ & Individual composting units & $2.900 .000,00$ & $551.000,00$ & $3.451 .000,00$ \\
\hline \multicolumn{2}{|c|}{ TOTAL } & $132.852 .212,00$ & $25.241 .920,28$ & $158.094 .132,28$ \\
\hline
\end{tabular}

Source: data processing Feasibility Study Services for elaboration of technicaleconomic documentation for the realization of selective waste collection system, Volume 1 - Written Parts, According to GD 907/2016 [11] 
Table no.3 General estimate of the project

Variant II - Containers 1.1 sqm. from plastic

\begin{tabular}{|c|c|c|c|c|}
\hline \multirow[t]{2}{*}{ No. } & \multirow[t]{2}{*}{$\begin{array}{l}\text { NAME OF } \\
\text { EXPENDITURE } \\
\text { CHAPTERS }\end{array}$} & $\begin{array}{l}\text { VALUE } \\
\text { without VAT }\end{array}$ & VAT & $\begin{array}{l}\text { VALUE } \\
\text { including VAT }\end{array}$ \\
\hline & & Lei & Lei & Lei \\
\hline 1 & 2 & 3 & 4 & 5 \\
\hline \multicolumn{5}{|c|}{ CHAPTER 1. EXPENSES PT. OBTAINING AND LAND PLANNING } \\
\hline TOT & L CHAPTER 1 & 0,00 & 0,00 & 0,00 \\
\hline \multicolumn{5}{|c|}{$\begin{array}{l}\text { CHAPTER 2. EXPENDITURE PT. ACHIEVING THE UTILITIES NECESSARY FOR } \\
\text { THE INVESTMENT OBJECTIVE }\end{array}$} \\
\hline TOT & L CHAPTER 2 & 0,00 & 0,00 & 0,00 \\
\hline \multicolumn{5}{|c|}{ CHAPTER 3. EXPENSES PT. DESIGN AND TECHNICAL ASSISTANCE } \\
\hline TOT & L CHAPTER 3 & $11.341 .060,00$ & $2.154 .801,40$ & $13.495 .861,40$ \\
\hline \multicolumn{5}{|c|}{ CHAPTER 4. EXPENDITURE FOR BASIC INVESTMENT } \\
\hline TOT & L CHAPTER 4 & $129.300 .812,00$ & 24.567.154,28 & $153.867 .966,28$ \\
\hline \multicolumn{5}{|c|}{ CHAPTER 5. OTHER EXPENSES } \\
\hline TOT & L CHAPTER 5 & $18.211 .389,60$ & $3.460 .164,02$ & $21.671 .553,62$ \\
\hline \multicolumn{5}{|c|}{ CHAPTER 6. EXPENDITURE FOR TECHNOLOGICAL TESTS AND TESTS } \\
\hline TOT & L CHAPTER 6 & 0,00 & 0,00 & 0,00 \\
\hline TOT & L DEVIZ GENERAL & $158.853 .261,60$ & $30.182 .119,70$ & $189.035 .381,30$ \\
\hline
\end{tabular}

Source: data processing Feasibility Study Services for elaboration of technicaleconomic documentation for the realization of selective waste collection system, Volume 1 - Written Parts, According to GD 907/2016 [11] 
- VALUE without VAT $\quad$ VAT $\quad$ Value with VAT

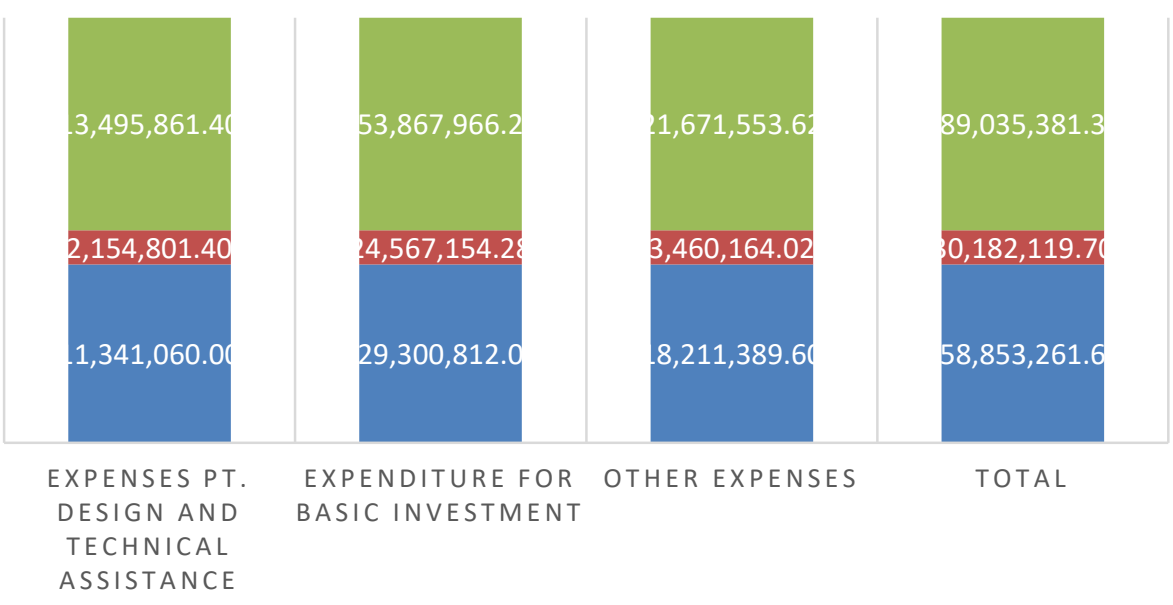

Graph no.3 General estimate of the project

Variant II - Containers $1.1 \mathrm{sqm}$. from plastic

Source: data processing Feasibility Study Services for elaboration of technicaleconomic documentation for the realization of selective waste collection system, Volume 1 - Written Parts, According to GD 907/2016 [11]

Table no.4 Basic investment expenses, Variant II

\begin{tabular}{|c|c|c|c|c|}
\hline \multicolumn{2}{|c|}{} & \multicolumn{3}{|c|}{ VALUE } \\
\cline { 3 - 5 } & \multicolumn{3}{|c|}{ Lei } \\
\cline { 3 - 5 } Denumire Obiect & Without VAT & VAT & Without VAT \\
\hline $\begin{array}{c}\text { Ob } \\
\text { Ob } \\
2\end{array}$ & $\begin{array}{c}\text { Underground waste } \\
\text { collection points }\end{array}$ & $96.582 .400,00$ & $18.350 .656,00$ & $114.933 .056,00$ \\
\hline $\begin{array}{c}\text { Ob } \\
3\end{array}$ & $\begin{array}{c}\text { Individual composting } \\
\text { system }\end{array}$ & $29.818 .412,00$ & $5.665 .498,28$ & $35.483 .910,28$ \\
\hline \multicolumn{2}{|c|}{$\begin{array}{c}\text { units } \\
\text { TOTAL }\end{array}$} & $129.300 .812,00$ & $24.567 .154,28$ & $153.867 .966,28$ \\
\hline
\end{tabular}

Source: data processing Feasibility Study Services for elaboration of technicaleconomic documentation for the realization of selective waste collection system, Volume 1 - Written Parts, According to GD 907/2016 [11] 


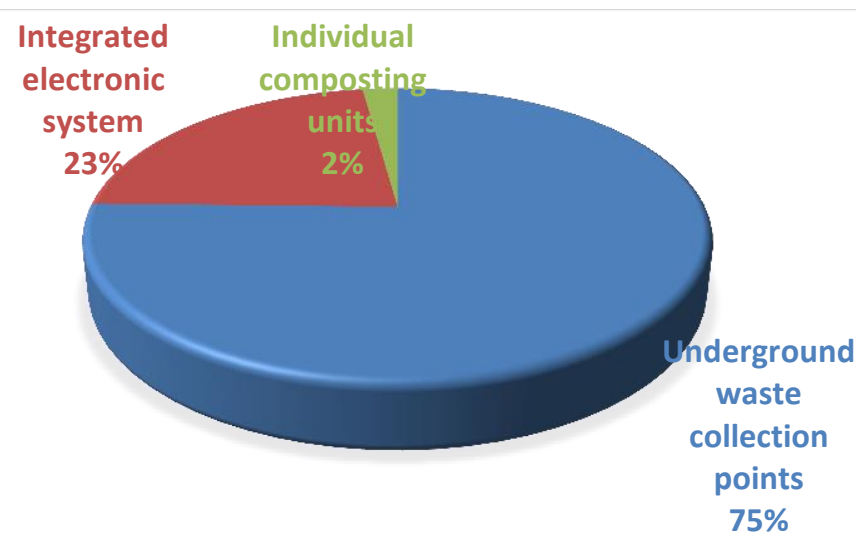

Graphic no.4 The structure of expenditures for the basic investment in both Source: data processing Feasibility Study Services for elaboration of technicaleconomic documentation for the realization of selective waste collection system, Volume 1 - Written Parts, According to GD 907/2016 [11]

Regardless of the chosen variant, the largest share in the expenditures for the basic investment is held by the underground collection points, representing about $75 \%$ in both variants. The costs for the integrated electronic system and for the individual composting units are the same in both variants, the difference in cost coming from the material used for the underground collection points.

There is a difference of 4,226,166 lei between the two variants. The use of plastic materials for the manufacture of underground collection points, respectively variant II is the cheapest. Without a collection system capable of effectively streamlining selective collection, these targets will not be achievable. The proposed investment represents the necessary foundation to achieve them through the result produced, namely waste collected selectively in the effective way.

By implementing the household points that can be used only by a certain group of established users, but especially through the electronic management system, it will be possible to apply the related public policies that lead to the efficiency of the service.

\section{Conclusions}

The investment involves the construction of compliant collection points, endowment with an electronic monitoring system and endowment with special containers for composting at source, to ensure at least the following: compliance with the legislation on selective collection; compliance with all conditions imposed by public health legislation; elimination of 
human and animal access to waste; ensuring access electronically, controlled, only by designated users; monitoring the behavior of dedicated users regarding the selection of waste, the local authority being able either to apply fines, if the collection rule is not observed, or to reward/stimulate (as the case may be) the selective collection of waste; increasing the degree of urban comfort (urban health and aesthetics); reduction of waste generation by composting at source.

The innovative character of this project is represented by the integrated electronic monitoring system - the containers that will be equipped with identification chip/tag and the collection truck will be equipped with chip and scale reading system, in order to establish an efficient statistics on waste generation/selective collection.

The realization of the proposed investment project would contribute to the fulfillment of the objectives assumed by Romania regarding the environmental protection and the increase of the recycling rate of the municipal waste. It would also help to improve the living conditions of citizens and avoid public health hazards by eliminating animals' access to waste. Under the current conditions, there is a process of hampering the implementation of efficient local policies in the field of municipal waste, as well as an increase in waste collection costs. The proposed project is proving to be innovative, bringing financial benefits by reducing additional costs, losses caused by vandalism, as well as theft of waste and containers. The financing of this investment project can be done from local budgets, but it can also be provided from European funds, where we can mention the opportunities offered by The European Green Deal's Investment Plan - the Sustainable Europe Investment Plan for public investments which finance the states in the next period with almost 1 trillion Euro.

Thus, Romania through its local public administrations must take the opportunity and prepare projects in order to adapt the environment policy to the EU requirements and targets.

\section{References}

[1] Bac DP. A history of the concept of sustainable development: literature review. Annals of the University of Oradea. Economic Science Series [nternet]. 2008 [cited 2020 July 19];17(2):581-585. Available from: http://steconomice.uoradea.ro/anale/volume/2008/v2-economy-andbusiness-administration/101.pdf

[2] Breukelman H, Krikke H, Lohr A. Failing services on urban waste management in developing countries: a review on symptoms, diagnoses, and 
interventions. Sustainability [Internet]. 2019 [cited 2020 July 19]; 11(24):6977. Available from: https://doi.org/10.3390/su11246977

[3] Abarca-Guerrero L, Maas G, Hogland W. Solid waste management challenges for cities in developing countries. Waste Management [Internet]. 2012 [cited 2020 July 19]; 33(1): 220-232. Available from: https://doi.org/10.1016/j.wasman.2012.09.008

[4] Hannan MA, Hossain Lipu MS, Mahmuda Akhtar, Begum RA, Md Abdullah Al Mamun, Aini Hussain, M.S. Mia, Hassan Basri. Solid waste collection optimization objectives, constraints, modeling approaches, and their challenges toward achieving sustainable development goals. Journal of Cleaner Production [Internet]. 2020 [cited 2020 November 7]; 277: 123557. Available from: https://doi.org/10.1016/i.jclepro.2020.123557

[5] Zhang Z, Wang X. Nudging to promote household waste source separation: Mechanisms and spillover effects. Resources, Conservation and Recycling [Internet]. 2020 [cited 2020 November 7]; 162: 105054. Available from: https://doi.org/10.1016/j.resconrec.2020.105054

[6] Zhang DQ, Tan SK, Gersberg RM. Municipal solid waste management in China: status, problems and challenges. Journal of Environment Management [Internet]. 2010 [cited 2020 November 7]; 91(8): 1623-1633. Available from: https://doi.org/10.1016/j.jenvman.2010.03.012

[7] Zhang S, Zhang M, Yu X, Ren H. What keeps Chinese from recycling: accessibility of recycling facilities and behavior. Resources, Conservation and Recycling [Internet]. 2016 [cited 2020 November 7]; 109:176-186. Available from: https://doi.org/10.1016/j.resconrec.2016.02.008

[8] Xu L, Ling M, Lu Y, Shen M. External influences on forming residents waste separation behavior: evidence households in Hangzhou China. Habitant International [nternet]. 2017 [cited 2020 November 7]; 63:21-33. Available from: https://doi.org/10.1016/j.habitatint.2017.03.009

[9] Eurostat database, https://ec.europa.eu/eurostat/web/productsdatasets/product? code $=$ sdg 1160

[10] European Commission. Sustainable development in the European Union Monitoring report on progress towards the SDGs in an EU context. Eurostat [nternet]. 2020 [cited 2020 November 7]. Available from: https://doi.org/10.2785/555257

[11] Ribić B, Kostić R, Holding Z, Petrushevski K, SKOPJE, Macedonia FYR, Garcia A, Charcon L, IAT, Bel J-B, ORDIF. Feasibility Study for elaboration of technical-economic documentation for the realization of selective waste collection system, Volume 1 - Written Parts, According to GD 907/2016. Bin2Grid [Internet]. 2016 August [cited 2020 November 7]. Available from: 
https://ec.europa.eu/research/participants/documents/downloadPublic?do cumentIds=080166e5ac5329b9\&appId=PPGMS

[12] Our Common Future - Brundtland Report, https://sustainabledevelopment.un.org/content/documents/5987ourcommon-future.pdf

[13] Romania's National Sustainable Development Strategy 2030, https://www.edu.ro/sites/default/files/Strategia-nationala-pentrudezvoltarea-durabila-a-Rom\%C3\%A2niei-2030.pdf

[14] The 2030 Agenda for Sustainable Development, https://ec.europa.eu/environment/international issues/pdf/UNEP $\% 20 \mathrm{En}$ v\%20Sustainability $\% 20$ and $\% 20$ SDGs.pdf 